\title{
Sugar cane bagasse as feedstock for second generation ethanol production. Part II: Hemicellulose hydrolysate fermentability
}

\author{
Gabriel J. Vargas Betancur ${ }^{1 \#} \cdot$ Nei Pereira Jr. ${ }^{1} \square$ \\ 1 Departamento de Engenharia Bioquímica, Universidade Federal do Rio de Janeiro, Rio de Janeiro, RJ, \\ Brazil \\ $\triangle$ Corresponding author: nei@eq.ufrj.br \\ Received October 18, 2009 / Accepted June 1, 2010 \\ Published online: September 15, 2010 \\ (C) 2010 by Pontificia Universidad Católica de Valparaíso, Chile
}

\begin{abstract}
Sugar cane bagasse is produced in Brazil as waste of the sugar and ethanol industries. This lignocellulosic material is a potential source for second-generation ethanol production; however a pretreatment stage is essential, which aims at removing the hemicellulose component by disorganizing the lignocellulosic complex. In this work sugar cane bagasse was pretreated by diluted acid hydrolysis resulting in xylose-rich hydrolysates, which could be fermented to ethanol by a strain of the yeast Pichia stipitis. Statistical approach was used to investigate the effects of factors associated with the diluted acid hydrolysis process (acid concentration, solid:liquid ratio and time of exposure) on the fermentability of different hydrolysates. The statistical analysis was useful for determining the effects of the individual factors and their interactions on the response variables. An acid concentration of $1.09 \%(\mathrm{v} / \mathrm{v})$, a solid:liquid ratio of 1:2.8 (g:ml), and an exposure time of 27 min were established and validated as the optimum pretreatment conditions for ethanol production from hemicellulose hydrolysates of sugar cane bagasse. Under these conditions, a hydrolysate with $50 \mathrm{~g} / \mathrm{l}$ of xylose, $6.04 \mathrm{~g} / \mathrm{l}$ of acetic acid, $0.55 \mathrm{~g} / \mathrm{l}$ of hydroxylmethylfurfural and $0.09 \mathrm{~g} / \mathrm{l}$ of furfural was obtained and its fermentation yielded roughly $20 \mathrm{~g} / \mathrm{l}$ of ethanol in $40 \mathrm{hrs}$.
\end{abstract}

Keywords: bioethanol, Pichia stipitis, xylose fermentation.

\section{INTRODUCTION}

The growth of population and the associated demand for fuel and goods coupled with more restrictive environmental regulations have intensified the research and development of renewable energy feedstocks to substitute for and/or to complement fossil fuel sources (Pereira Jr. et al. 2008). Lignocellulosic materials, especially agroindustrial residues, have been the subject of intense research since they are renewable sources of carbon and energy available in large amounts. Sugar cane bagasse is the main Brazilian agroindustrial residue, being produced at approximately 
$250 \mathrm{~kg}$ per ton of sugar cane (Zanin et al. 2000; Wyman et al. 2005). This lignocellulosic material is mainly composed of two polysaccharide fractions (cellulose and hemicellulose) and a polyphenolic macromolecule (lignin). Sugar cane hemicellulose is the second predominant fraction (23-30\%), and it is composed of heteroxylans, with a predominance of xylose, which is configured in a chain that can be chemically hydrolyzed (Sun and Cheng, 2002; Ververis et al. 2007). Diluted acid hydrolysis pretreatment of sugar cane bagasse allows the generation of a liquid phase (hemicellulose hydrolysate) rich in xylose, which can be used as substrate (buildingblock) for biotechnological and chemical processes (Lavarack et al. 2002; Fogel et al. 2005; Gámez et al. 2006).

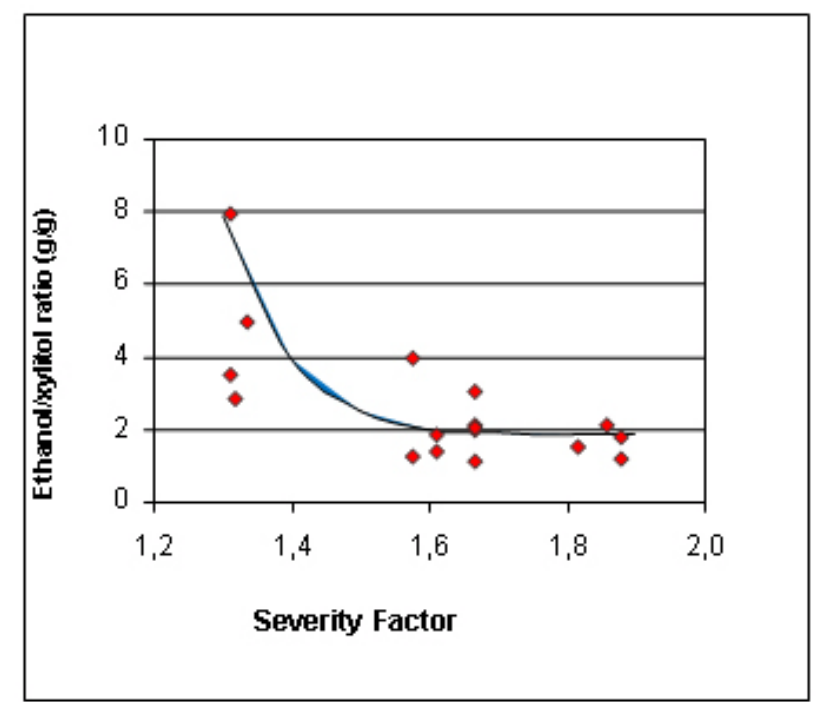

Fig. 1 The influence of the severity factor on ethanol/xylitol ratio.

The yeast Pichia stipitis is one of the best xylose-fermenting organisms to produce ethanol. Whereas in most bacteria the xylose metabolism proceeds via direct isomerization to xylulose, in yeasts and filamentous fungi the formation of xylulose occurs via a two-step reaction in which xylose is first reduced to xylitol by NADPHdependent xylose reductase, followed by oxidation of xylitol to xylulose by $\mathrm{NAD}^{+}$. dependent xylitol dehydrogenase. It is evident that under anaerobic conditions there will be an overproduction of $\mathrm{NADH}$, resulting in a redox imbalance, which blocks the metabolic activity, since it can not be reoxidized in the absence of oxygen. However, in xylose-fermenting yeasts, such as cells of Pichia stipitis, these two first enzymes of xylose catabolism display dual coenzyme specificity. Thus, the reducing equivalents produced in the second reaction can be used for the initial step of xylose metabolism, therefore reducing the overproduction of $\mathrm{NADH}$, and consequently alleviating the cell redox imbalance. Nonetheless, micro aeration conditions will be necessary, since this dual specificity does not occur in the same extent. In the next step, phosphoketolase incorporates inorganic phosphate into xylulose to produce xylulose-5-P, which is converted into glyceraldehyde 3-P and fructose 6-P in the pentose phosphate pathway. Both are converted into pyruvate through the glycolytic pathway, which gives origin to ethanol through two sequential reactions (decarboxylation and 
Sugar cane bagasse as feedstock for second generation ethanol production. Part II

reduction) (Toivari et al. 2001; Jin and Jeffries, 2004; Jeffries, 2006; Pereira Jr. et al. 2008).

Table 1. Levels for each factor in the experimental design.

\begin{tabular}{cccccc}
\hline Factor & $\begin{array}{c}\text { Axial point } \\
(-\alpha)\end{array}$ & $\begin{array}{c}\text { Low level } \\
(-1)\end{array}$ & $\begin{array}{c}\text { Central level } \\
(0)\end{array}$ & $\begin{array}{c}\text { High level } \\
(+1)\end{array}$ & $\begin{array}{c}\text { Axial point } \\
(+\alpha)\end{array}$ \\
\hline $\begin{array}{c}\text { Time of exposure } \\
\text { (min) }\end{array}$ & 27 & 40 & 60 & 80 & 93 \\
$\begin{array}{c}\text { Acid concentration } \\
(\% \mathrm{vv})\end{array}$ & 0.50 & 0.75 & 1.13 & 1.50 & 1.75 \\
$\begin{array}{c}\text { Solid:liquid ratio } \\
(\mathrm{g}: \mathrm{ml})\end{array}$ & $1: 3.3$ & $1: 3.0$ & $1: 2.5$ & $1: 2.0$ & $1: 1.7$ \\
\hline
\end{tabular}

Yeast growth and sugar fermentation can be inhibited by different compounds generated during the acid hydrolysis of hemicellulose. Xylose, the main hemicellulose-derivative pentose, and hexoses may be dehydrated during acid hydrolysis into furfural and 5-hydroxymethyl furfural, respectively, which have been reported as potent inhibitors of yeast enzymes such as alcohol dehydrogenase, aldehyde dehydrogenase and pyruvate dehydrogenase (Modig et al. 2002; Balat et al. 2008). Also, Pampulha and Loureiro-Dias (1990) showed the action of the undissociated form of acetic acid that diffuses into yeast cells, reducing the cytoplasm $\mathrm{pH}$ and modify the control of glycolysis involving enolase and phosphorilating enzymes. Phowchinda et al. (1995) showed the inhibitory effect of acetic acid on the growth and fermentation activity of Saccharomyces cerevisiae and indicated that it had more impact on biomass synthesis than on ethanol production. Nonetheless, the simultaneous presence of these compounds has a greater inhibitory effect on yeast metabolism than do their individual presence (Palmqvist et al. 1999).

Thus, this work aimed at characterizing the individual effects of sulfuric acid concentration, solid:liquid $(S: L)$ ratio and the time of exposure, as well as their synergic effects on the hydrolysate fermentability and its relation with the concentrations of inhibitors by a strain of the yeast Pichia stipitis.

\section{MATERIALS AND METHODS}

\section{Microorganism and inoculum preparation}

The fermentation assays were carried out with the yeast Pichia stipitis 5774 from the Central Bureau voor Schimmelcultures (CBS) - The Netherlands. The strain was stored at $5^{\circ} \mathrm{C}$ in agar slant medium containing xylose $(5 \mathrm{~g} / \mathrm{l})$, yeast extract $(2 \mathrm{~g} / \mathrm{l})$ and peptone $(5 \mathrm{~g} / \mathrm{l})$ (Pereira Jr. and Bu'lock, 1994). Cell propagation was performed in two stages using hydrolysate obtained in pretreatment condition of $121^{\circ} \mathrm{C}$ during $40 \mathrm{~min}$ with a solid:liquid ratio of $1: 2$ (g of bagasse: $\mathrm{mL}$ of $1 \%$ sulfuric acid solution). In the first stage, cells were transferred from the agar slant to liquid medium containing $25 \%$ hydrolysate, and in the second stage the hydrolysate content was increased to $50 \%$. 

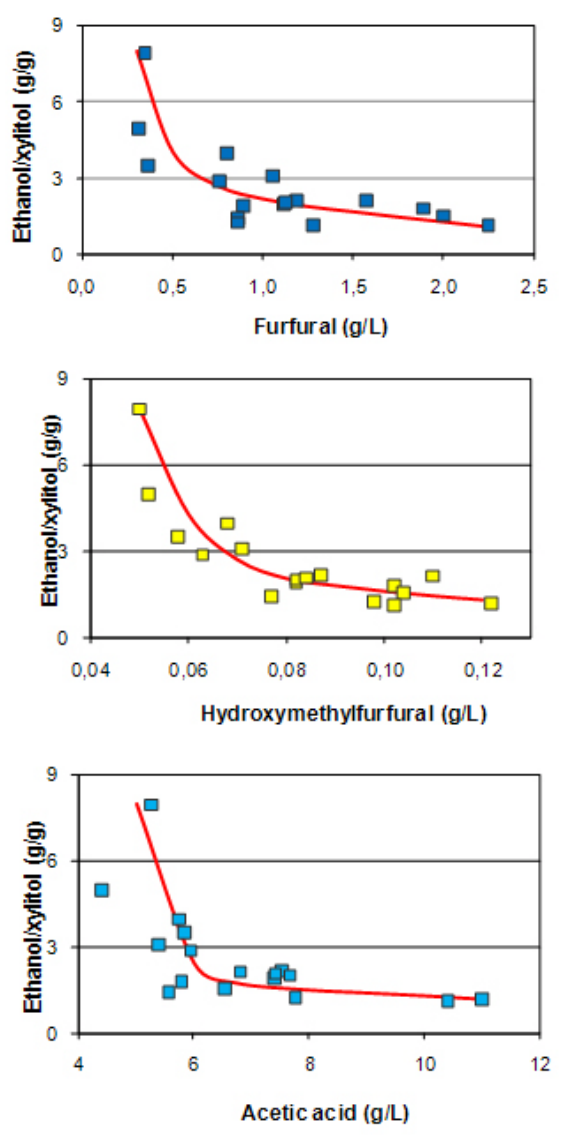

Fig. 2 Effect of inhibitors on the ethanol/xylitol ratio.

Then cells necessary for each fermentation assay was separated from media by centrifugation at $4000 \mathrm{rpm}$ during $4 \mathrm{~min}$. For the propagation stages, the liquid medium was supplemented with urea $(2.5 \mathrm{~g} / \mathrm{l}) ; \mathrm{KH}_{2} \mathrm{PO}_{4}(2.2 \mathrm{~g} / \mathrm{l})$; yeast extract $(4 \mathrm{~g} / \mathrm{l})$ and $40 \mathrm{ml} / \mathrm{l}$ of a solution of salts (Pereira Jr. and Bu'lock, 1994).

\section{Fermentation assays}

Hemicellulose hydrolysates were obtained by diluted acid pretreatment using a central composite design with the following factors: time of exposure, concentration of sulfuric acid and solid-liquid ratio for a total of 17 experimental runs (central point performed in triplicate). The temperature was kept constant at $121^{\circ} \mathrm{C}$ (Betancur and Pereira Jr., 2010). The levels for each variable are shown in Table 1. 
After acid pretreatment, the liquid phase (hemicellulose hydrolysate) was separated from the solid by a pressure filter set within the reaction system (Santa Anna et al. 2007). Then, the $\mathrm{pH}$ of the liquid phase was adjusted to 6 by addition of $\mathrm{Ca}(\mathrm{OH})_{2}$, and the generated $\mathrm{CaSO}_{4}$ was separated by filtration. The liquid phase, called hemicellulose hydrolysate, had its sugar and inhibitor contents determined, and was used for fermentation assays.

The fermentations were carried out in conical flasks $(500 \mathrm{ml})$ containing $200 \mathrm{ml}$ of hydrolysate supplemented with the same nutrients as the propagation media. The fermentation media were inoculated with an initial cell concentration of $10 \mathrm{~g} / \mathrm{l}$ and performed on a rotary shaker (Excella E25-New Brunswick) at $200 \mathrm{rpm}$ for $48 \mathrm{hrs}$ at $30^{\circ} \mathrm{C}$ with an initial $\mathrm{pH}$ of 6 . To validate the fermentability of the hydrolysates in the best pretreatment condition, a fermentation was performed in a 2I-Biostat B fermenter (B. Braun) containing $800 \mathrm{ml}$ of medium with control of agitation (250 rpm), temperature $\left(30^{\circ} \mathrm{C}\right)$ and air supply $(0.02 \mathrm{vvm})$. The $\mathrm{pH}$ was maintained at 6 by the addition of $2 \mathrm{M} \mathrm{NaOH}$ or $2 \mathrm{M} \mathrm{HCl}$ solutions.

Table 2. Xilose content in the hydrolysate and response variables for the fermentability of hydrolysates by $P$. stipitis after 48 hrs.

\begin{tabular}{|c|c|c|c|c|c|c|c|}
\hline Experiment & $\begin{array}{l}\text { Severity } \\
\text { Factor }\end{array}$ & $\begin{array}{c}\text { Xylose } \\
(\mathrm{g} / \mathrm{l})\end{array}$ & $\begin{array}{c}\text { Ethanol } \\
(\mathrm{g} / \mathrm{l})\end{array}$ & $\begin{array}{c}\text { Xylitol } \\
(\mathrm{g} / \mathrm{l})\end{array}$ & $\begin{array}{c}Y_{\text {Ethanol/S }} \\
(\mathrm{g} / \mathrm{g})\end{array}$ & $\begin{array}{c}Y_{\text {Xylitol/s }} \\
(g / g)\end{array}$ & $\begin{array}{c}\text { Ethanol/ } \\
\text { xylitol } \\
\text { ratio } \\
(\mathrm{g} / \mathrm{g})\end{array}$ \\
\hline 1 & 1.31 & 56.96 & 17.71 & 5.04 & 0.31 & 0.09 & 3.51 \\
\hline 2 & 1.61 & 67.53 & 22.46 & 11.91 & 0.34 & 0.18 & 1.89 \\
\hline 3 & 1.31 & 51.56 & 18.47 & 2.33 & 0.36 & 0.05 & 7.94 \\
\hline 4 & 1.61 & 48.64 & 14.85 & 10.47 & 0.30 & 0.21 & 1.42 \\
\hline 5 & 1.58 & 71.12 & 19.40 & 15.49 & 0.27 & 0.21 & 1.25 \\
\hline 6 & 1.88 & 76.25 & 13.73 & 11.72 & 0.18 & 0.15 & 1.17 \\
\hline 7 & 1.58 & 51.38 & 18.28 & 4.60 & 0.35 & 0.09 & 3.97 \\
\hline 8 & 1.88 & 54.31 & 17.48 & 9.71 & 0.32 & 0.18 & 1.80 \\
\hline 9 & 1.34 & 44.80 & 18.45 & 3.70 & 0.41 & 0.08 & 4.98 \\
\hline 10 & 1.81 & 68.63 & 20.88 & 13.64 & 0.30 & 0.19 & 1.53 \\
\hline 11 & 1.67 & 82.11 & 16.23 & 14.39 & 0.27 & 0.24 & 1.13 \\
\hline 12 & 1.67 & 44.87 & 18.69 & 6.09 & 0.41 & 0.13 & 3.07 \\
\hline 13 & 1.32 & 60.47 & 20.65 & 7.23 & 0.34 & 0.12 & 2.86 \\
\hline 14 & 1.86 & 63.04 & 22.55 & 10.61 & 0.35 & 0.16 & 2.13 \\
\hline 15 & 1.67 & 61.51 & 18.98 & 8.87 & 0.30 & 0.14 & 2.14 \\
\hline 16 & 1.67 & 63.91 & 20.31 & 10.16 & 0.31 & 0.16 & 2.00 \\
\hline 17 & 1.67 & 59.84 & 20.68 & 9.99 & 0.34 & 0.16 & 2.07 \\
\hline
\end{tabular}




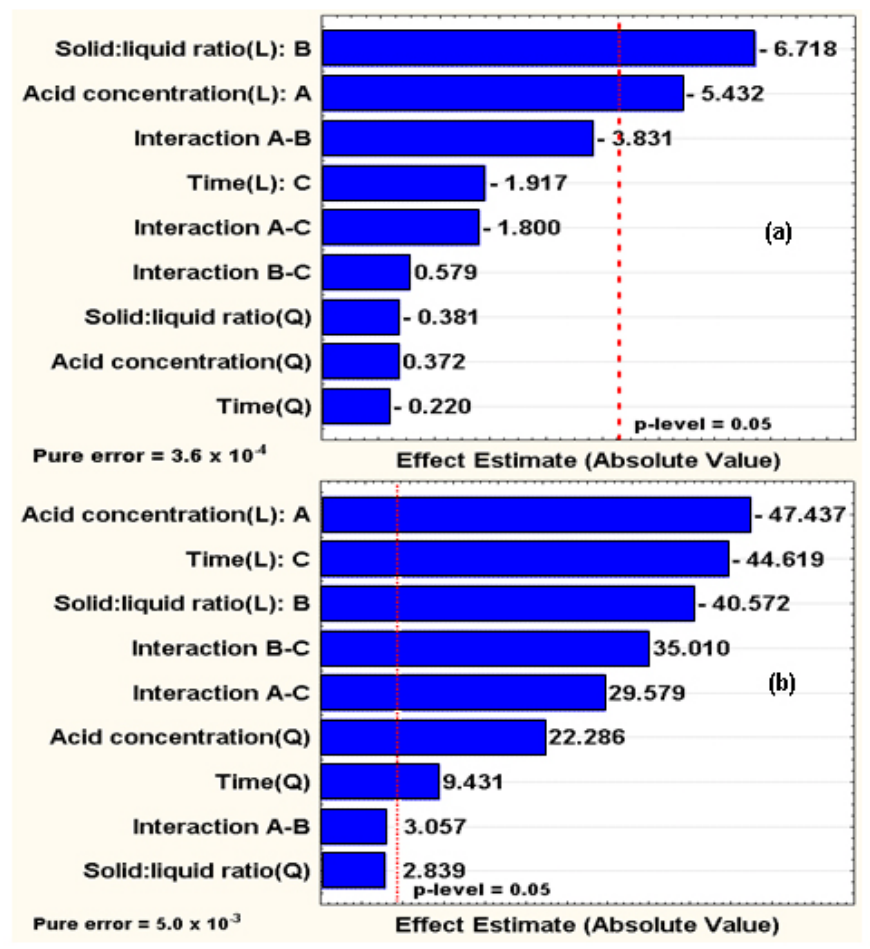

Fig. 3 Pareto charts of standardized effects for (a) ethanol yield and (b) ethanol/xylitol ratio (g/g). (L): Linear effect; (Q): Quadratic effect.

\section{Analytical methods}

Xylose, ethanol and xylitol concentrations in the hydrolysates and fermented media were determined by high performance liquid chromatography (HPLC) using an Aminex HPX-87P column (Bio-rad) maintained at $65^{\circ} \mathrm{C}$ and with a differential refractive index detector (Waters). Furfural, hydroxymethylfurfural and acetic acid concentration was determined by HPLC using a KC811 column (Shodex) with a UV detector at $230 \mathrm{~nm}$ (Waters). The cell concentration was determined by a correlation between cell dry mass and cell suspension absorbance at $570 \mathrm{~nm}$.

The hydrolysis factors were used to determinate the severity factor (Equation 1), as proposed by Schell et al. (2003), and its relation with the response variables was established. Additionally, the effects of each individual factor and its interactions were analyzed using the software STATISTICA 6.0 (StatSoft, 2002).

Severity factor $=\log _{10}\left(\right.$ timeexp $\left.\left[\frac{\text { Temperature }-100}{14.75}\right]\right)-\mathrm{pH}$

[Equation 1] 


\section{RESULTS AND DISCUSSION}

The hydrolysates characteristics were discussed previously (Part I of this work). Hydrolysates fermentability was investigated by using a strain of the yeast $P$. stipitis and monitoring the final concentrations of ethanol and xylitol after $48 \mathrm{hrs}$ (Table 2). Total consumption of xylose was achieved for the majority of the experiments, except for those coded as 2, 3, 6, 11 and 15, corresponding to high severity conditions and with residual xylose concentrations below $5 \mathrm{~g} / \mathrm{l}$.

The final ethanol concentration varied between $13.73 \mathrm{~g} / \mathrm{l}$ and $22.55 \mathrm{~g} / \mathrm{l}$ with xylitol production as an intermediate metabolite in concentrations ranging from $2.33 \mathrm{~g} / \mathrm{l}$ to $15.49 \mathrm{~g} / \mathrm{l}$. The highest ethanol concentrations (experiments 2, 10, 13, 14, 16 and 17) were not coincident with the highest xylose content in the hydrolysates (experiments 5, 6 and 11). Xylitol synthesis increased as xylose content increased in the hydrolysate, especially in experiments 5 and 11 . This result confirms that hydrolysis under severe conditions (1.7), as used in experiment 11, leads to high xylose content in the hydrolysate, yet no efficient ethanol production is achieved during the fermentation. Additionally, the two best ethanol/xylitol ratios $(7.94 \mathrm{~g} / \mathrm{g}$ and $4.98 \mathrm{~g} / \mathrm{g}$ ) were obtained from pretreatments carried out under moderate severity conditions (1.31 and 1.34 for experiments 3 and 9, respectively).

Table 3. Predicted process conditions, using empirical models, for process optimization and their experimental validation.

\begin{tabular}{|c|c|c|}
\hline Pretreatment conditions & Predicted conditions & \\
\hline Acid concentration (\% vv) & \multicolumn{2}{|c|}{1.09} \\
\hline $\mathrm{S}: \mathrm{L}$ ratio $(\mathrm{g}: \mathrm{ml})$ & \multicolumn{2}{|c|}{$1: 2.8$} \\
\hline Time of exposition (min) & \multicolumn{2}{|c|}{27} \\
\hline $\begin{array}{l}\text { Response variables for the } \\
\text { fermentation process }\end{array}$ & Predicted values & Experimental values \\
\hline Ethanol concentration $(\mathrm{g} / \mathrm{l})$ & $20.58 \pm 0.80$ & 19.05 \\
\hline Xylitol concentration (g/l) & $2.77 \pm 0.49$ & 2.86 \\
\hline
\end{tabular}

No correlation was found between the severity factor and ethanol concentration or yield. In contrast, the ethanol/xylitol ratio decreased dramatically when the severity factor increased (Figure 1). It is well known that xylitol is a fungal-compatible solute (Davis et al. 2000), and its accumulation during fermentation is considered to be a cellular response to the medium's adversities, be it by the redox imbalance that can be caused under oxygen restriction, high substrate concentration or the presence of inhibitors that may be generated during the pretreatment stage, particularly if high severity conditions are imposed.

Figure 2 shows the effect of inhibitors on the yeast metabolic product distribution during fermentation. The ethanol/xylitol ratio decreases when the concentration of inhibitors (furfural, hydroxymethylfurfural and acetic acid) increases. Initially, the ethanol/xylitol ratio decreases sharply when the concentration of furfural increases from $0.4 \mathrm{~g} / \mathrm{l}$ to $0.8 \mathrm{~g} / \mathrm{l}$, and then it continues to diminish, but more slowly. The same performance was observed for hydroxymethylfurfural and acetic acid, with sharp declines for concentrations up to $0.07 \mathrm{~g} / \mathrm{l}$ and $6 \mathrm{~g} / \mathrm{l}$, respectively. Both furans and acetic acid are reported to be inhibitors of Pichia stipitis yeast (Modig et al. 2002; Balat et al. 2008). The increase in xylitol yield as the severity factor rises can be 
ascribed to the increasing concentration of inhibitors during acid pretreatment that are generated in harsher conditions. It seems that xylitol, apart from being a compatible solute, has other protective functions for the cell.

The linear effect of the $S: L$ ratio and the acid concentration were the most important factors determining ethanol yield (Figure $3 a$ ) and the only ones with statistical significance $(p<0.05)$. All factors during the acid pretreatment showed statistically significant effects on the ethanol/xylitol ratio, except for the quadratic effect of the $S: L$ ratio and its interaction with the acid concentration (Figure $3 \mathrm{~b}$ ). The negative values of the effects indicate that high ethanol/xylitol ratios, ideal for the ethanol fermentation of hemicellulose hydrolysates, require short exposure times and low acid concentrations and $S: L$ ratios, within the range evaluated. However, these conditions lead to the generation of hydrolysates with low xylose content and consequently low ethanol concentration in the fermentation process, which is not technologically sound. Figure $3 \mathrm{~b}$ also shows that the linear effect of time of exposure is negative, which means that as exposure time gets shorter the ethanol/xylitol ratio gets higher, within the range evaluated.

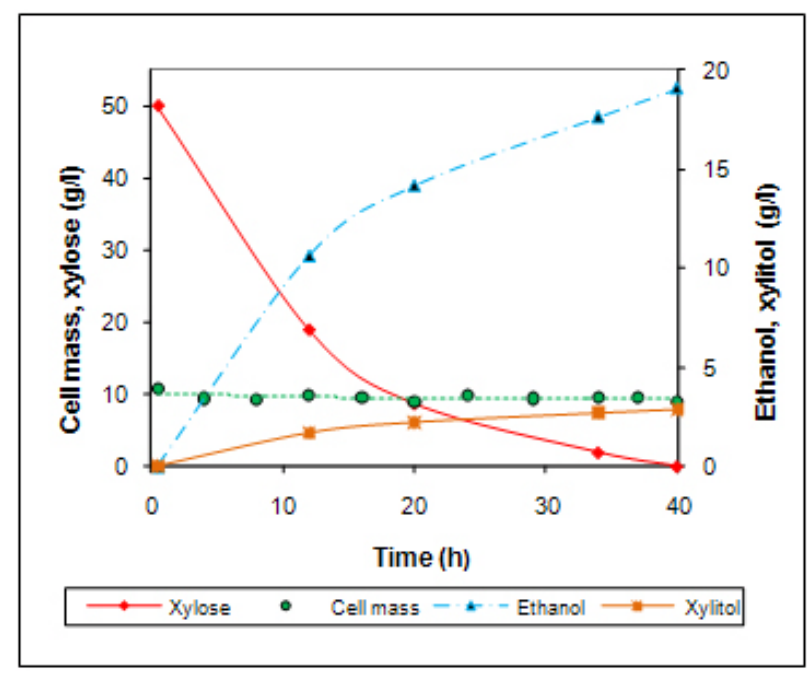

Fig. 4 Fermentation performance of hemicellulosic hydrolysate obtained from optimized conditions.

Empirical models for each response variable (Equation 2) were obtained and used to determine the conditions for achieving the best performance of the pretreatment hydrolysis and the fermentation process. The final ethanol concentration model was not statistically significance, which resulted in a low coefficient of determination $\left(\mathrm{R}^{2}=\right.$ 0.47). On the other hand, the empirical model for xylitol concentration had a very good coefficient of determination $\left(R^{2}=0.92\right)$. In the case of the ethanol and xylitol yields during the fermentation process, the empirical models had coefficients of determination of 0.73 and 0.88 , respectively, corroborating the greater mathematical model fit for xylitol than for ethanol yield. For the ethanol/xylitol ratio, the empirical model showed statistical significance and a good coefficient of determination $\left(\mathrm{R}^{2}=\right.$ 0.88). 


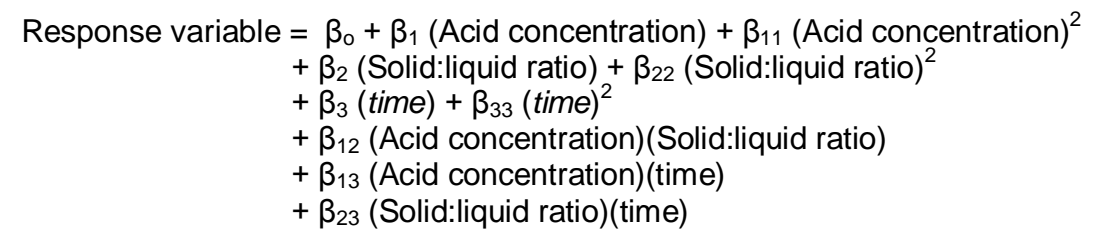

[Equation 2]

\section{$\beta$ : Empirical Coefficient}

The pretreatment conditions yielding the best process performance were determined using the desirability function (Equation 3) (StatSoft, 2002) under optimization criteria to maximize the xylose concentration, ethanol concentration and ethanol/xylitol ratio and to minimize the xylitol concentration and yield. The experimental results of the optimized conditions (Table 3) were within the predicted confidence intervals for the xylitol and ethanolconcentrations, even without statistical significance for the ethanol concentration model.

$D=\left(d_{1}\left(Y_{1}\right) \times d_{2}\left(Y_{2}\right) \times \ldots \times d_{k}\left(Y_{k}\right)\right)^{1 / K} \quad$ [Equation 3]

$D$ : overall desirability

$Y_{i}$ : response variable

$d_{i}(Y i)=0$ for undesirable value and increase $\operatorname{tod}_{i}(Y i)=1$ for desirable value

$k$ : number of response variables

Figure 4 shows the hydrolysate fermentation carried out under the pretreatment predicted conditions. The process began with fast xylose uptake and ethanol production. Both rates diminished after $15 \mathrm{hrs}$ and total xylose consumption was achieved at the end of $40 \mathrm{hrs}$ cell growth was not observed, which may be due to the hydrolysate composition and fermentation conditions, especially the oxygen supply, which was low enough $\left(\mathrm{Q}_{\mathrm{v}}=0.02 \mathrm{vvm}\right)$ to assure ethanol fermentation in detriment to cell growth (Jeffries et al. 2007).

\section{CONCLUDING REMARKS}

The severity factor showed inversely proportional effect on ethanol/xylitol ratio, whilst no tendency was observed with the ethanol concentration. Furfural, hydroxymethylfurfural, and acetic acid concentrations have strong influence on the metabolic distribution products during the hydrolysate fermentation. The use of statistical analysis allowed the individual effect of every acid pretreatment factor on hydrolysates fermentability to be determined. Also, the conditions dictated by the statistical analysis were validated experimentally with good agreement with the predictions. In the experimental validation a hydrolysate with $50 \mathrm{~g} / \mathrm{l}$ of xylose, $6.04 \mathrm{~g} / \mathrm{l}$ of acetic acid, $0.55 \mathrm{~g} / \mathrm{l}$ of hydroxylmethylfurfural and $0.09 \mathrm{~g} / \mathrm{l}$ of furfural was obtained and final ethanol concentration of $19.1 \mathrm{~g} / \mathrm{l}$ was achieved during fermentation. 


\section{REFERENCES}

BALAT, Mustafá; BALAT, Havva and ÖZ, Cahide. Progress in bioethanol processing. Progress in Energy and Combustion Science, October 2008, vol. 34, no. 5, p. 551-573. [CrossRef]

BETANCUR, Gabriel J. Vargas and PEREIRA Jr., Nei. Sugar cane bagasse as feedstock for second generation ethanol production. Part I: diluted acid pretreatment optimization. Electronic Journal of Biotechnology, May 2010, vol. 13, no. 3. [CrossRef]

DAVIS, Diana J.; BURLAK, Christopher and MONEY, Nicholas P. Osmotic pressure of fungal compatible osmolytes. Mycological Research, July 2000, vol. 104, no. 7, p. 800-804. [CrossRef]

FOGEL, Rafael; GARCIA, Rafaela R.; OLIVEIRA, Rebeca; PALACIO, Denise; MADEIRA Luciana and PEREIRA Jr., Nei. Optimization of acid hydrolysis of sugarcane bagasse and investigations on its fermentability for production of xylitol by Candida guilliermondii. Applied Biochemistry and Biotechnology, March 2005, vol. 122, no. 1-3, p. 741-752. [CrossRef]

GÁMEZ, Sara; GONZÁLEZ-CABRIALES, Juan Jose; RAMíREZ, José Alberto; GARROTE, Gil and VÁZQUEZ, Manuel. Study of the hydrolysis of sugar cane bagasse using phosphoric acid. Journal of Food Engineering, May 2006, vol. 74, no. 1, p. 78-88. [CrossRef]

JEFFRIES, Thomas W. Engineering yeasts for xylose metabolism. Current Opinion in Biotechnology, June 2006, vol. 17, no. 3, p. 320-326. [CrossRef]

JEFFRIES, Thomas W.; GRIGORIEV, Igor V.; GRIMWOOD, Jane; LAPLAZA, José M.; AERTS, Andrea; SALAMOV, Asaf; SCHMUTZ, Jeremy; LINDQUIST, Erika; DEHAL, Paramvir; SHAPIRO, Harris; JIN, Yong-Su.; PASSOTH, Volkmar and RICHARDSON, Paul M. Genome sequence of the lignocellulose-bioconverting and xylose-fermenting yeast Pichia stipitis. Nature Biotechnology, March 2007, vol. 25, no. 3, p. 319-326. [CrossRef]

JIN, Yong-Su and JEFFRIES, Thomas W. Stoichiometric network constraints on xylose metabolism by recombinant Saccharomyces cerevisiae. Metabolic Engineering, July 2004, vol. 6, no. 3, p. 299-238. [CrossRef]

LAVARACK, B.P.; GRIFFIN, G.J. and RODMAN, D. The acid hydrolysis of sugarcane bagasse hemicellulose to produce xylose, arabinose, glucose and other products. Biomass and Bioenergy, November 2002, vol. 23, no. 5, p. 367-380. [CrossRef]

MODIG, Tobias; LIDEN, Gunnar and TAHERZADEH, Mohammad J. Inhibition effects of furfural on alcohol dehydrogenase, aldehyde dehydrogenase and pyruvate dehydrogenase. Biochemical Journal, May 2002, vol. 363, no. 3, p. 769-776. [CrossRef]

PALMQVIST, Eva; GRAGE, Halfdan; MEINANDER, Nina Q. and HAHN-HÄGERDAL, Bärbel. Main and interaction effects of acetic acid, furfural, and $p$-hydroxybenzoid acid on growth ethanol productivity of yeast. Biotechnology and Bioengineering, April 1999, vol. 63, no. 1, p. 46-55. [CrossRef]

PAMPULHA, M.E. and LOUREIRO-DIAS, M.C. Activity of glycolytic enzymes of Saccharomyces cerevisiae in the presence of acetic acid. Applied Microbiology and Biotechnology, December 1990, vol. 34, no. 3, p. 375-380. [CrossRef]

PEREIRA Jr., Nei and BU'LOCK, John Desmond. The ionic character of the environment in the flocculation of Pichia stipitis. Brazilian Journal of Microbiology, June 1994, vol. 25, no. 1, p. 51-56.

PEREIRA Jr., Nei; COUTO, Maria Antonieta P.G. and SANTA ANNA, Lidia Maria M. Series on biotechnology: Biomass of lignocellulosic composition for fuel ethanol production within the context of biorefinery. Rio de Janeiro, Amigadigital Press, 2008. 47 p. ISBN 978-85903967-3-4.

PHOWCHINDA, O.; DÉLIA-DUPUY, M.L. and STREHAIANO, P. Effects of acetic acid on growth and fermentative activity of Saccharomyces cerevisiae. Biotechnology Letters, February 1995, vol. 17, no. 2, p. 237-242. [CrossRef]

SANTA ANNA, Lidia Maria Melo; PEREIRA Jr., Nei; VARGAS BETANCUR, Gabriel Jaime; BEVILAQUA, Juliana Vaz; GOMES, Absai da Conceição and MENEZES, Emerson Pires. Processo de produção de etanol a partir do hidrolisado da fração hemicelulosica do bagaço de cana-de-açúcar em reator do tipo presa. Instituto Nacional de Propriedade Industrial, patent PI 0505 299-9, Brasil, 2007.

SCHELL, Daniel J.; FARMER, Jody; NEWMAN, Milli and McMILLAN, James D. Dilute-sulfuric acid pretreatment of corn stover in pilot-scale reactor. Investigation of yields, kinetics and 
enzimatic digestibilities of solids. Applied Biochemistry and Biotechnology, March 2003, vol. 105, no. 1-3, p. 69-85. [CrossRef]

STATSOFT, Inc. STATISTICA (data analysis software system), version 6.0, Statsoft, Inc., 2002. Available from internet: http://www.statsoft.com.

SUN, Ye and CHENG, Jiayang. Hydrolysis of lignocellulosic materials for ethanol production: a review. Bioresource Technology, May 2002, vol. 83, no. 1, p. 1-11. [CrossRef]

TOIVARI, Mervi H.; ARISTIDOU, Aristos; RUOHONEN, Laura and PENTTILÄ, Merja. Conversion of xylose to ethanol by recombinant Saccharomyces cerevisiae: Importance of Xylulokinase (XKS1) and oxygen availability. Metabolic Engineering, July 2001, vol. 3, no. 3, p. 236-249. [CrossRef]

VERVERIS, C.; GEORGHIOU, K.; DANIELIDIS, D.; HATZINIKOLAOU, D.G.; SANTAS, P.; SANTAS, R. and CORLETI, V. Cellulose, hemicelluloses, lignin and ash content of some organic materials and their suitability for use as paper pulp supplements. Bioresource Technology, January 2007, vol. 98, no. 2, p. 296-301. [CrossRef]

WYMAN, Charles E.; DALE, Bruce E.; ELANDER, Richard T.; HOLTZAPPLE, Mark; LADISCH, Michael R. and LEE, Y.Y. Coordinated development of leading biomass pretreatment technologies. Bioresource Technology, December 2005, vol. 96, no. 18, p. 1959-1966. [CrossRef]

ZANIN, Gisella M.; SANTANA, Cesar C.; BON, Elba P.; GIORDANO, Raquel C.L.; De MORAES, Flavio F.; ANDRIETTA, Silvio R.; De CARVALHO NETO, Carlos Coelho; MACEDO, Isaias C.; FO, Djalma Lahr; RAMOS, Luiz P. and FONTANA, José D. Brazilian bioethanol program. Applied Biochemistry Biotechnology, March 2000, vol. 84-86, no. 1-9, p. 11471161. [CrossRef]

\section{How to cite this article:}

VARGAS, G.J. and PEREIRA, N. Sugar cane bagasse as feedstock for second generation ethanol production. Part II: Hemicellulose hydrolysate fermentability. Electronic Journal of Biotechnology, September 2010, vol. 13, no. 5. http://dx.doi.org/10.2225/vol13-issue5fulltext-8 